\title{
Cellular therapies for treating pain associated with spinal cord injury
}

Lawrence Leung ${ }^{1,2,3}$

\begin{abstract}
Spinal cord injury leads to immense disability and loss of quality of life in human with no satisfactory clinical cure. Cell-based or cell-related therapies have emerged as promising therapeutic potentials both in regeneration of spinal cord and mitigation of neuropathic pain due to spinal cord injury. This article reviews the various options and their latest developments with an update on their therapeutic potentials and clinical trialing.
\end{abstract}

Keywords: Cellular therapies, Spinal cord injury, Pain

\section{Spinal cord injury-demography and economic impact}

Causes of spinal cord injury (SCI) include falls, motor vehicle accidents, community violence, sports injury and work-related injuries. Annual incidence rate of SCI ranges from 15 to 40 per million [1] with an average age of onset at under 30 . There is male sex predominance over female of up to 5:1, with cervical and thoracic regions being the commonest region of trauma [2-5]. Depending on the severity and level(s) of lesion, spinal cord injury leads to a combination of loss of sensory, motor and autonomic functions, translating to clinical scenarios of paraplegia, tetraplegia, aphagia, incontinence and neuropathic pain. This plethora of sequelae leads to catastrophic loss of quality of life of these young and otherwise healthy patients. Economically it also translates to immense economic costs due to loss of work productivity and the demand of life-long supportive care. It has been estimated that annual costs of health care (including hospitalisation and rehabilitation) for an average patient with spinal cord injury range from US $\$ 21,450$ in Veterans Health Facilities [6] to US\$88,585 in a community base setting [7].

\section{Neuropathic pain after spinal cord injury}

About $65-85 \%$ of patients will suffer from pain after spinal cord injury and amongst them, 1/3 will have

\footnotetext{
Correspondence: leungl@queensu.ca

'Centre of Neurosciences Study, Queen's University, 18 Stuart Street, Kingston, ON K7L 3N6, Canada

Full list of author information is available at the end of the article
}

severe pain [8]. Those who experience pain for longer than 6 months are likely to continue for the next 3 to 5 years [9], with a propensity to worsen over time with other associated symptoms like fatigue, weakness and memory loss [10]. The type of pain experienced after spinal cord injury can be classified as neuropathic, musculoskeletal, visceral and others [11]. In a longitudinal sample of 100 patients followed up to 26 weeks after traumatic spinal cord injury, $40 \%$ of them reported musculoskeletal pain, 36\% reported neuropathic pain at the level of lesion and $16 \%$ reported neuropathic pain below level of lesion [12]. Neuropathic pain is more common with incomplete lesions of the cord and is more often associated with cervical as compared to other levels of injury [12]. Like other types of neuropathic pain, pain due to spinal cord injury remains as a major challenge in pain management and so far the commonest therapy is with opioids, albeit a $32 \%$ long term efficacy [13].

Cellular and molecular basis for neuropathic pain due to spinal cord injury

A typical non-transection injury of the spinal cord results in various degrees of contusion and compression, causing mechanical disruption of microvascular structures resulting in hemorrhages, intravascular thrombosis and vasospasm. This subsequently leads to local hypoperfusion, hypoxia and ischemic damage. Paradoxically, a period of reperfusion of the ischemic tissue occurs when vasospastic blood vessels relax, and this produces free-radicals, notably peroxynitrite $\left(\mathrm{ONOO}^{-}\right)$, which progressively oxidize fatty acids in the cellular membranes 
(lipid peroxidation). This in turn causes pathological membrane depolarisation and massive release of glutamate from the injured axons, which subsequently overstimulates post-synaptic N-Methyl-D-aspartic acid (NMDA) and $\alpha$-amino-3-hydroxy-5-methyl-4-isoxazolepropionic acid (AMPA) receptors. As a result, cytoplasmic calcium inside the injured axons rises abruptly due to influx from extracellular compartment and also release from intracellular stores [14], triggering off a cascade of calcium-dependent processes like activation of lytic enzymes (calpains, phospholipase $\mathrm{A}_{2}$ and lipoxygenase), disruption of mitochondrial function and even more free radicals generation (nitric oxide and peroxynitrite)[15], culminating in apoptosis and final death of the axons. Excessive stimulation of NMDA/AMPA/kainite receptors by glutamate also leads to a similar influx of sodium ions into the intracellular compartment of the axons, causing repolarisation failure and loss of axonal function. Outside the injured axons, an inflammatory cascade commences with invasion of neutrophils and monocytes/macrophages which secret an array of immuno-active mediators like cytokines (TNF- $\alpha$, IL-1 $\beta$ and IL-6), chemokines (CX3CL1 and CCL2) and neurotrophic factors (NGF and BDNF) which often contribute to further inflammatory damage and pave the way for neuropathic pain $[16,17]$. A summary of events which happen after a spinal cord injury can be found in a schematic flowchart in Figure 1. In recent years, significant progress has been made in profiling the intricate roles of these neuroinflammatory mediators and the astroglial system in the pathogenesis of neuropathic pain, and the topic has been extensively reviewed elsewhere [18-21]. Details are beyond the scope of this paper but worth noting is the latest concept of neuropathic pain as a neuro-immune process with its severity and chronicity determined by the net balance of concurrent pro-inflammatory (neurodegenerative) and antiinflammatory (neuroprotective) mechanisms [22].

\section{Cell-based strategies for treating neuropathic pain associated with spinal cord injury Using primary adrenal medullary/chromaffin tissue or cells}

Descending tracts from the periaqueductal gray (PAG), locus coeruleus, parabrachial nucleus, nucleus raphe magnus, reticular formation, anterior pretectal nucleus, thalamus and cerebral cortex are known to modulate afferent nociceptive signals [23] at the spinal cord. This is thought to mediate via an array of neurotransmitters like brain-derived neurotrophic factors (BDNF), 5hydroxytrytamine (5-HT), noradrenaline, $\gamma$-aminobutyric acid (GABA), $\beta$-endorphins, enkephalins and galanin. Since initial discovery of the colour reaction of the adrenal medulla to chromate salt in 1865 by Henle [24], the term chromaffin cells refer to those that contain granules or vesicles which retain the chromium particles upon chromaffin reaction. It was not until 1953 that Hillarp et al. [25] and Blaschko et al. [26] independently reported the findings of catecholamines in the granular portion of abstract of bovine adrenal medullae. Subsequent work in the 1980's revealed a collection of antinociceptive neuropeptides and neurotrophins in these chromaffin cells [27-29] which in theory, can be utilised on their own or with catecholamines $[30,31]$ in a minipump logic for analgesic purposes. This cradled the pioneering work of Sagen et al. in 1986 who implanted bovine chromaffin cells into the subarachnoid space of lumbar spine of rats and found significant analgesia which was dose-related to the amount of chromaffin cells [32]. They obtained similar findings with allogeneic transplants of adrenal medullary tissue [33], documenting significant increase of met-enkephalin-like immunoreactivity in the spinal cord cerebral spinal fluid (CSF)[34] and prolongation of analgesia with the use of intrathecal enkephalinase [35], substantiating the role of opioid peptides in the analgesic mechanisms. Using similar adrenal medullary allografts transplanted into the subarachnoid space of rat spinal cord, they demonstrated reduction of chronic pain in rats modeled for arthritis [36] and peripheral neuropathy [37]. These promising data propelled the use of cadaveric adrenal medullary transplants into subarachnoid space of five palliative patients with intractable cancer pain [38] (Table 1), amongst them there was $80 \%$ response rate with significant reduction of pain and demand for opioids when they were followed up to 1 year. Two other clinical studies from France using adrenal medullary transplants, one as a pilot with two patients having chronic pain [39](Table 1), the other a Phase II study with 15 patients diagnosed with intractable cancer pain [40], reported similar clinical improvement plus increase in CSF met-enkephalin levels. Albeit such promising results, the use of adrenal medullary tissues carries three limitations: (i) the minimal effective dose is still unclear and the clinical response did not seem to be dosedependent; (ii) the time limit of the donor medullary tissue to maintain its viability and antinociceptive potency is uncertain [41]; (iii) donor shortage in clinical situation. To circumvent these difficulties, isolated bovine chromaffin cells encapsulated by semipermeable polymer membranes were successfully employed in sheep recipients as a functional xenogeneic transplant with a dose-related response [42]. This led to the development of a prototype implant which was pilot-tested in seven patients with severe non-cancer type of chronic pain [43] (Table 1), with data showing acceptable levels of safety and device retrievability without the need of immunosuppression. 


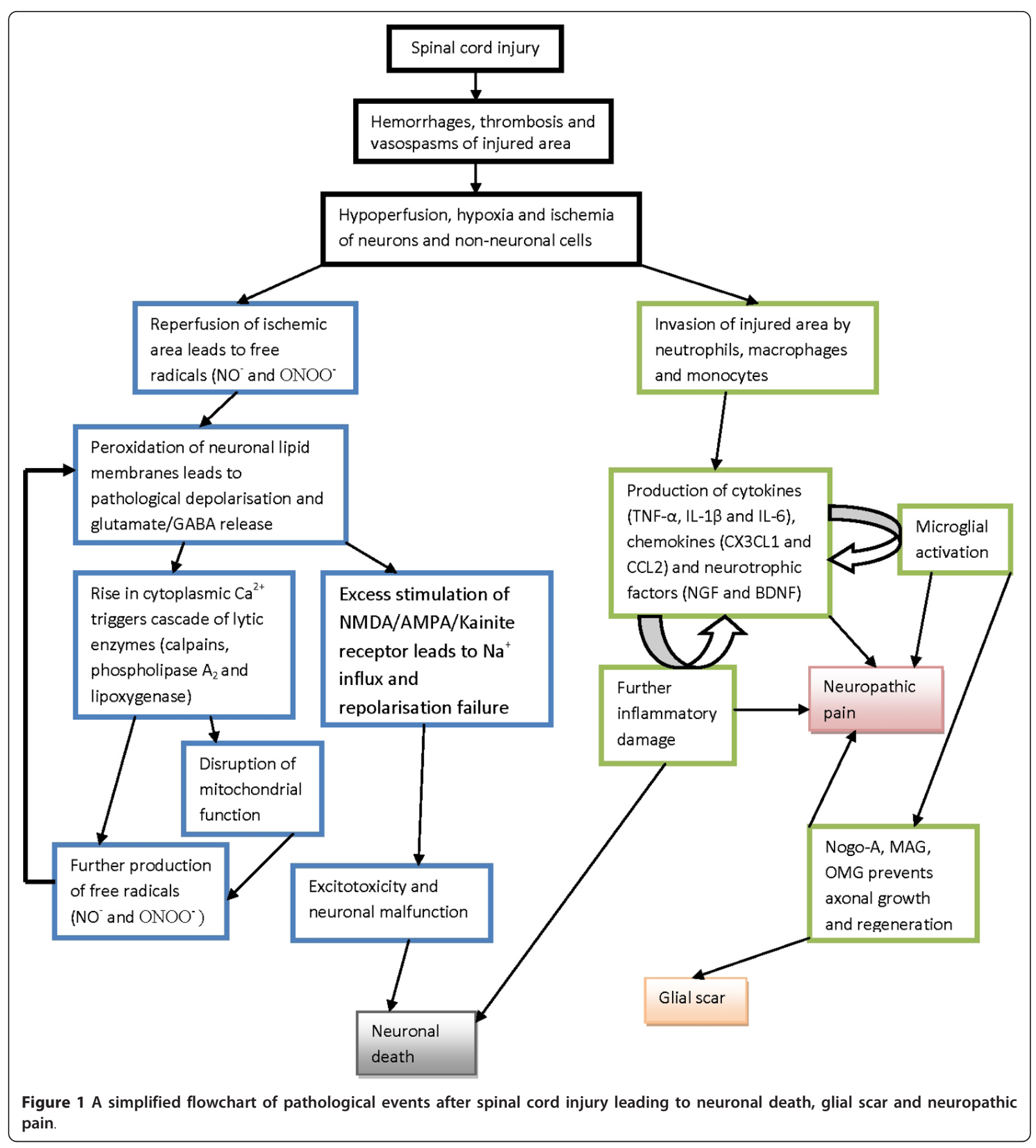

\section{Using immortalised cell lines}

Details of immortalising cell lines prepared under laboratory conditions are beyond the scope of this paper. Suffice to say in the research of neuropathic pain, Eaton et al. $[62,63]$ made significant contribution in immortalising two main cell lines which helped advance the study of cellular therapy for pain. One of them is a neural cell line RN33B, derived from E13 brainstem raphe and immortalised with SV40 temperature-sensitive allele of large $\mathrm{T}$ antigen (tsTag), which are then conditioned to proliferate at $33^{\circ} \mathrm{C}$ and stop proliferation at $39^{\circ} \mathrm{C}$. RN33B can further be transfected with cDNA either for synthesizing galanin [64], BDNF [65] or GABA [62], either of which when transplanted in the 
Table 1 Synopsis of clinical studies using cellular therapies for chronic pain

\begin{tabular}{|c|c|c|c|}
\hline Modality & Methods & Outcome & References \\
\hline \multirow{4}{*}{$\begin{array}{l}\text { Primary adrenal } \\
\text { medullary/ } \\
\text { chromaffin tissue }\end{array}$} & $\begin{array}{l}\text { Cadaveric adrenal medullary transplants into } 5 \text { subjects } \\
\text { with intractable cancer pain }\end{array}$ & $\begin{array}{l}80 \% \text { response rate with reduced demand for opioid } \\
\text { analgesia }\end{array}$ & {$[38]$} \\
\hline & Allograft to lumbar in 2 subjects with chronic cancer pain & $\begin{array}{l}\text { Clinical improvement with increase in CSF Met- } \\
\text { enkephalin levels }\end{array}$ & [39] \\
\hline & $\begin{array}{l}\text { Encapsulated bovine chromaffin cells implanted as a } \\
\text { device in subarachnoid space of } 7 \text { subjects with chronic } \\
\text { pain }\end{array}$ & $\begin{array}{l}\text { Reduction of morphine requirement from } 30-100 \% \\
\text { within a period of } 41-176 \text { days post-implantation }\end{array}$ & [43] \\
\hline & $\begin{array}{l}\text { Phase II trial with allograft to CSF space in } 15 \text { subjects } \\
\text { with cancer pain }\end{array}$ & $\begin{array}{l}\text { Reduction of intra-thecal morphine dosage and } \\
\text { increase in CSF Met-enkephalin levels }\end{array}$ & {$[44]$} \\
\hline \multirow[t]{3}{*}{$\begin{array}{l}\text { Bone marrow- } \\
\text { MSC }\end{array}$} & $\begin{array}{l}\text { Bone-marrow MSC co-cultured with autoimmune T-cells } \\
\text { given to } 2 \text { human subjects with chronic SCl }\end{array}$ & $\begin{array}{l}\text { Recovery of motor and sensory functions up to } 8 \\
\text { spinal cord levels within } 6 \text { months }\end{array}$ & {$[45]$} \\
\hline & $\begin{array}{l}\text { Open label case-control study with } 64 \text { subjects ( } 44 \text { as trial } \\
\text { and } 20 \text { as control) using monthly intrathecal autologous } \\
\text { MSC transplant for } 6 \text { months }\end{array}$ & $\begin{array}{l}\text { No significant differences found in terms of ASIA score, } \\
55.8 \% \text { of treated subjects developed neuropathic pain }\end{array}$ & {$[46]$} \\
\hline & $\begin{array}{l}\text { Three cycles of allogeneic MSC treated CD34 cells given } \\
\text { over } 14 \text { months to a subject with incomplete SCl }\end{array}$ & $\begin{array}{l}\text { Reduction of neuropathic pain by } 70 \% \text { and resumption } \\
\text { of motor and sexual activities }\end{array}$ & {$[47]$} \\
\hline \multirow[t]{5}{*}{$\begin{array}{l}\text { Bone marrow } \\
\text { transplant }\end{array}$} & $\begin{array}{l}\text { Unmanipulated autologous bone marrow transplant to } 20 \\
\text { subjects with complete SCl }\end{array}$ & Regime generally safe and feasible & {$[48]$} \\
\hline & $\begin{array}{l}\text { Phase I/II open label trial with } 35 \text { subjects having } \\
\text { complete SCI receiving autologous bone marrow with } \\
\text { GM-CSF }\end{array}$ & $\begin{array}{l}\text { Clinical improvement in } 30.4 \% \text { of subjects with no } \\
\text { complication of tumour or neuropathic pain formation }\end{array}$ & {$[49]$} \\
\hline & $\begin{array}{l}\text { Uncontrolled series in Ecuador with } 52 \text { subjects with SCl } \\
\text { given bone marrow stem cells }\end{array}$ & Clinical improvements described & {$[50]$} \\
\hline & $\begin{array}{l}\text { Phase I/II study with } 297 \text { patients with SCI receiving single } \\
\text { unmanipulated autologous bone marrow cells }\end{array}$ & $\begin{array}{l}\text { Regime relatively safe with improvement in motor/ } \\
\text { sensory functions in } 1 / 3 \text { subjects }\end{array}$ & [51] \\
\hline & $\begin{array}{l}\text { Clinical pilot with } 30 \text { subjects with } \mathrm{SCl} \text { receiving single } \\
\text { dose of ex-vivo expanded bone marrow transplant }\end{array}$ & $\begin{array}{l}\text { Clinical improvement in subjects with }<6 \text { months } \\
\text { injury, not sure if effects due to spontaneous recovery }\end{array}$ & {$[52]$} \\
\hline \multirow[t]{4}{*}{$\begin{array}{l}\text { Olfactory } \\
\text { ensheathing cells } \\
\text { (OEC) }\end{array}$} & $\begin{array}{l}\text { Phase I/lla study with } 6 \text { subjects with thoracic paraplegia } \\
\text { receiving autologous OEC and followed up at } 1 \text { yr and } 3 \\
\text { yrs }\end{array}$ & 1 out of 6 subjects had mild clinical improvement & {$[53,54]$} \\
\hline & $\begin{array}{l}\text { Uncontrolled trial with } 16 \text { subjects receiving heterologous } \\
\text { OEC from aborted foetuses }\end{array}$ & No improvement mentioned & {$[55]$} \\
\hline & $\begin{array}{l}\text { Pilot study with seven subjects (ASIA class A) having } \\
\text { olfactory mucosa autografts (OMA) into spinal cord } \\
\text { lesions, later escalated to a prospective study with } 20 \\
\text { subjects }\end{array}$ & $\begin{array}{l}\text { Feasible and safe procedure with improvement with } \\
\text { ASIA scores, bladder sensations and sphincter } \\
\text { functions, with additional radiological improvements in } \\
\text { the prospective study }\end{array}$ & {$[56,57]$} \\
\hline & $\begin{array}{l}\text { Pilot study with } 5 \text { subjects with chronic SCl receiving } \\
\text { OMA }\end{array}$ & $\begin{array}{l}\text { No significant improvement, development of syrinx in } \\
\text { one subject and myelomalacia in other } 4\end{array}$ & {$[58]$} \\
\hline Schwann cells & $\begin{array}{l}\text { Pilot study with } 4 \text { subjects receiving autologous transplant } \\
\text { from sural nerve cultures }\end{array}$ & $\begin{array}{l}\text { Overall no adverse effects with improvement in only } \\
\text { one subject }\end{array}$ & {$[59]$} \\
\hline Anti-TNF- $\alpha$ & $\begin{array}{l}\text { One report of current usage of etanercept in one subject } \\
\text { with accident of } T 7 \text { cord transection }\end{array}$ & $\begin{array}{l}\text { Significant reduction of inflammation and motor } \\
\text { improvement }\end{array}$ & {$[60]$} \\
\hline Anti-Nogo-A & $\begin{array}{l}\text { Phase I study with anti-Nogo-A given to }>50 \text { subjects } \\
\text { within } 14 \text { days of SCl }\end{array}$ & Still under evaluation & [61] \\
\hline
\end{tabular}

lumbar subarachnoid space of rats with experimental chronic constricting injury (CCI), demonstrated significant reduction of neuropathic pain $[62,64,65]$. The second cell line is bovine chromaffin cell line, where the immortalised cells possess immuno-reactivities for metenkephalin, galanin GABA and 5-HT without further gene transfection with minimal in vivo tumorigenicity [63]. Despite the theoretical advantage of its unlimited supply, these immortalised cell lines still carry oncogenic potential and hence none of them has yet been approved for clinical trial as a cellular therapy for spinal cord injury without demonstrating a fool-proof reassurance of dis-immortalisation. Also, there is as yet a reliable method of controlling the immortalised cells to deliver the specific dose of neurotrophins for the desired effect on neuropathic pain. That is especially relevant when the secreted neurotrophins produce antagonistic effects on pain at different concentrations: an excellent example will be BDNF, where Miki et al. [44](Table 1) demonstrated that systemic infusion of BDNF to rats with ligated spinal nerves relieved mechanical neuropathic pain at a lower concentration of $1 \mu \mathrm{g} / \mathrm{h}$ and, 
paradoxically, enhanced the pain response when given at a higher dose of $20 \mu \mathrm{g} / \mathrm{h}$.

\section{Using other engineered cell lines}

$\mathrm{Xu}$ et al. [66] transfected and immortalised astrocytes with cDNA carrying the human preproenkephalin gene (hPPE) which was combined with the tetracycline-controlled (Tet-on) expression system, and these astrocytes were implanted into the subarachnoid space of rats with CCI. The group documented significant rise of spinal enkephalin in these rats as regulated by doxycycline administration in a dose-dependent fashion, with alleviation of thermal and mechanical hyperalgesia. In a recent experiment [67], the same group applied similar protocols using preprogalanin cDNA (without tetracyclinecontrolled expression system) and found increased spinal galanin with overall reduction of thermal hyperalgesia and mechanical allodynia. In a different note, Liu et al. [68] in 2004 engineered a replication-incompetent herpes simplex virus (HSV) vector expressing one isoform of the human glutamic acid decarboxylase (GAD) and transfected rats with T13 spinal cord hemisection via subcutaneous inoculation. The recipient rats exhibited less neuropathic pain presumably due to increased levels of GABA at the dorsal root ganglion (DRG). Lee et al. [69] conducted a similar study but in addition, explored the effects of another strain of non-replicating HSV vector expressing proenkephalin. He found the reduction in pain behaviour was less significant with the proenkephalin-expressing vectors. In 2009, Miyazato et al. [70] injected GAD expressing HSV-vectors into the bladder walls of rats with SCI and found alleviation of detrusor overactivity, supporting the hypothesis that the GAD gene therapy enhanced GABA-mediated suppression of neuropathic signals. Encouraged by these experimental findings, Wolfe et al. [71] embarked upon a Phase I single-centre, open-label, dose-escalating trial using a clinical grade of replication-incompetent HSV virus expressing human preproenkephalin gene (called NP2). Patients with intractable pain due to malignancy below the angle of the jaw were enrolled and NP2 virus was administered by innoculation. At time of writing, the trial is still in progress and results are pending.

\section{Using stem cells}

Use of stem cells has phenomenally advanced regenerative medicine and equally has aroused enormous medico-legal controversies, especially regarding the use of embryonic stem cells derived from human beings. In the last decade, mesenchymal stem cells (MSC) have remained a major focus of stem cells research. MSC are found in the adult bone marrow with a mesodermal origin and are capable of differentiating into cells that constitute the blood, adipose tissue, connective tissues, the vascular and urogenital system [72]. In vitro, MSC can be expanded easily from a small amount of bone marrow aspirate with stable phenotype and genotype, and are easily transported in various methods and formulations from the bench to the bedside [73]. Moreover, MSC migrate to sites of tissue injury with extraordinary immunosuppressive properties and their ability to differentiate into neurons and astrocytes have been documented both in vitro and in vivo [74]. In addition, MSC can enhance synaptic transmission and promote neuronal network in mice model of neurodegeneration [75], making MSC a prime candidate for nervous system repair. In the context of neuropathic pain, direct injection of human mesenchymal stem cells (hMSC) into the cerebral ventricle of mice with spinal nerve injury (SNI) reduced formation of neuropathic pain [76]. So far, three clinical studies have been published regarding the use of bone marrow MSC for spinal cord injury. In 2006, basing on their previous findings that human MSC derived from adult bone marrow can trans-differentiate into neural stem cells when co-cultured with auto-reactive T-lymphocytes [77], Moviglia et al. [45] (Table 1) reported clinical extension of spinal cord function in two patients when given these MSC pre-primed with anti- $\mathrm{T}$ cells autoserum and noted no apparent adverse effects. In 2009, Kishk et al. [46] (Table 1) conducted an open label case-control study with 64 patients who had SCI within an average of 3.6 years. 44 patients consented to monthly autologous MSC transplant for 6 months, which was given intrathecally. The 20 patients who refused therapy served as controls. All patients were evaluated for adverse effects and functional improvements 12 months after the therapy. Results were disappointing as no significant between-group improvements as per clinical measures were detectable, with additional adverse effects of spasticity in $9.3 \%$ and neuropathic pain in $55.8 \%$ of subjects who received therapy. In 2010, Ichim et al. [47](Table 1) gave three cycles of combined allogeneic MSC and expanded umbilical cord blood CD34 cells intrathecally over a period of 14 months to a patient with incomplete spinal cord injury. They reported significant reduction of neuropathic pain from an intermittent 10/10 to weekly $3 / 10$ basing on the visual analogue scale (VAS). Other improvements in terms of muscle, bowel and sexual function were also noted without any adverse effects.

\section{Using bone marrow and bone marrow stem cell transplant}

Instead of using the specific mesenchymal portion of bone marrow, several clinical studies have employed autologous whole bone marrow transplant or its stem cell abstract for treating spinal cord injury. In 2006, a case study from Czech republic [48](Table 1) recruited 
20 patients with complete SCI and were given unmanipulated autologous bone marrow transplant intra-arterially 10 to 467 days post-injury. Results showed general level of safety with improvement in terms of sensory and motor functions mostly amongst the acutely injured group, and the authors cautioned that the observed benefits might be confounded by the natural recovery processes. Yoon et al. [49](Table 1) conducted a Phase I/II open label non-randomised study in 2007 with 35 patients diagnosed with complete spinal cord injury. They received autologous bone marrow cell transplant together with granulocyte macrophage-colony stimulating factor (GM-CSF) within 8 weeks of injury directly at the site of spinal lesion. No adverse effects of tumour, cysts or neuropathic pain was observed up to 10.4 months after injury, with improvement of clinical measures up to $30.4 \%$. In 2008, Geffner et al. [50](Table 1) in Ecuador also described improvement in clinical measures with relatively minor adverse effects when bone marrow stem cells were given to an uncontrolled series of 52 patients with SCI via multiple routes of administration(spinal cord injection, spinal canal injection and intravenous). By far the largest Phase I/II study was conducted in 2009 by Kumar et al. [51](Table 1) in India. 297 patients who had SCI were enrolled and they received a single treatment of unmanipulated autologous mononuclear bone marrow cells transplantation via lumbar puncture. They were then followed for up to a mean of 20.4 months and approximately $1 / 3$ of patients showed some form of sensory or motor improvements, which were dependent on the absolute number of CD34 + cells transplanted. The group concluded that such treatment was relatively safe without any serious adverse effects. However, not all SCI clinical studies using bone marrow transplants yielded convincing benefits. A pilot conducted by Pal et al. [52](Table 1) in 2009 recruited thirty patients with complete SCI within 6 months of injury. They received a single treatment of autologous ex-vivo expanded bone marrow transplant via lumbar puncture and showed no harmful effects but benefits were only apparent for patients with less than 6 months of injury. However, as most patients with acute SCI will recover spontaneously within 3 to 18 months regardless, it is necessary to have a large enough sample size to demonstrate validity and statistical significance for true benefits of any therapeutic intervention [78]. Hence, Pal et al. rightly questioned if their observed improvements were genuinely due to treatment itself.

\section{Other cell-related strategies for SCI with implications to neuropathic pain Olfactory ensheathing cells (OECs)}

The olfactory mucosa is a fascinating anatomical area with incessant regenerative potential. It contains both multipotent progenitor cells and olfactory ensheathing cells (OECs), the former capable of differentiating into both neural and non-neural cells [79], and the latter capable of promoting axonal remyelination and regeneration after injury. It is of interest to note that OECs, though normally associated with axons of the first cranial nerve, do not myelinate the olfactory nerve per se. They only assume a myelinating prototype when transplanted to the vicinity of axons of larger diameter [80]. Research findings in the last decade have suggested that transplanting OECs into damaged spinal cord promotes axonal regeneration and remyelination, facilitating overall functional recovery of the spinal cord [81-83]. However, this view has been challenged when OEC graft transplanted to rats with rhizotomy failed to enable axonal regeneration beyond the dorsal root entry zone [84-86]. Moreover, controversy has been intense as to whether these regeneration-capable olfactory cells are OECs or in fact, Schwann cells. OECs resemble Schwann cells so closely in terms of biochemistry, microscopic morphology and molecular transcription that it is often impossible to distinguish between the two [80]. Basing on their earlier findings with genomic studies that calponin is a definitive phenotypic marker for OECs which is not shared by Schwann cells [87], Kawaja's group found that primary cultures of olfactory mucosa and bulb often contained a mixture of calponin-positive OECs and calponinnegative Schwann cells [88]. In other words, what is normally thought as "OECs culture" will be invariably contaminated by Schwann cells. Hence, the concept of OECs remyelinating damaged axons without the influence of Schwann cells might need revision. In a recent authoritative review, Kawaja et al. [89] exhaustively critiqued the technical strategies of obtaining and culturing OECs from olfactory mucosa or olfactory bulb of various animal species and humans, the different biomarkers used for identifying OECs, and offered a stateof-the-art opinion on the controversy of Schwann cell contamination amongst OECs. Thus said, experimental data have shed enough light for clinical trialing of OECs in patients with SCI. In 2004, Mackay-Sim et al. conducted a Phase I/IIa study using autologous transplantation of OECs in six patients with thoracic paraplegia with follow-up at one year [53] and three years [54] (Table 1), and the group concluded that such procedure seemed to be safe with no consequences of iatrogenic neuropathic pain or tumour formation. However, only one out of the six subjects showed improvement in sensory function over three segments of the thorax. In 2006, Huang et al. [55](Table 1) followed 16 patients with SCI who received heterologous OECs transplants from aborted foetuses and they found no major adverse effects or pathology within 38 
months of the procedure. There was, however, no mention of functional improvement or clinical symptoms. More favourable outcomes were reported by Lima et al. [56] (Table 1) who conducted a pilot study with seven patients having olfactory mucosal autografts (OMA) directly transplanted into their spinal cord lesions. They exhibited good improvements in bladder sensation, anal sphincter function and overall paraplegic scores according to the American Spinal Injury Association (ASIA). There was also corresponding remyelination of the lesional sites as documented by spinal MRI scan. The same group hence proceeded to a prospective study in 2010 [57] (Table 1) using the same protocol with a larger sample size of 20 patients. They confirmed similar clinical benefits and radiological improvements as with their initial pilot study. However, such promising findings were not replicated in the five patients recruited by Chhabra et al. [58] (Table 1), for which the authors attributed to the procedures involved. In addition, adverse effects of syrinx formation in one subject and extension of myelomalacia in four subjects were reported.

\section{Schwann cells}

Discovered by Theodore Schwann (1810-1882), Schwann cells are a major component of the peripheral nervous system derived embryonically from the neural crest cells. Schwann cells grow in juxtaposition to axons and also myelinate them. Following axonal injury, Schwann cells de-differentiate into the non-myelinating phenotype and proliferate, secreting an array of growth modulators like collagen IV, laminin and fibronectin in the surrounding domain [90]. In experimental models of SCI, Schwann cells were found to be present in the regenerated areas [91-93], which helped to regenerate the axons with various neurotrophic factors like nerve growth factor (NGF) [94], brain-derived neurotrophic factor (BDNF)[95], Neutrotrophin-3 (NT-3)[96], glial derived growth factor (GDNF)[97] and pleiotrophin (PTN, HB-GAM) [98]. In particular, Schwann cells seem to exhibit distinct motor or sensory phenotypes as per immunoreactivity towards PTN which direct regenerating axons towards the specific phenotypes [99]. Recent improvement in cell harvesting and proliferation techniques have enabled human Schwann cells to be obtained in a sufficiently large and purified amount for reparative purpose of spinal cord injury. Saberi et al. [59](Table 1) studied the effects of human autologous Schwann cell transplant purified from autologous sural nerve culture in four patients with mid-throacic spinal cord injury. They reported lack of adverse effects overall with improvement in sensory and motor functions in only one patient, and MRI scanning failed to show any corresponding changes in white matter.
Specific anti-cytokine treatment: the rise and fall of TNF- $\alpha$ As mentioned above, SCI leads to a myriad of neuroinflammatory mediators which contribute to the pathogenesis of neuropathic pain. Amongst them, tumor necrosis factor-alpha (TNF- $\alpha$ ) is one of the most extensively studied which can be detected promptly after experimental models of spinal cord injury [100]. First discovered in 1891 from a mixed extract of Streptococcus pyogenes and Serratia marcescens bacteria [101] and later characterised with tumor-regression activity [102], TNF- $\alpha$ belongs to a superfamily of ligand/receptor proteins called the tumor necrosis factor/tumor necrosis factor receptor superfamily proteins (TNF/TNFR SFP). TNF- $\alpha$ possess a trimeric symmetry with a structural motif called the TNF homology domain (THD), which is shared with all other members of the TNF proteins. This THD binds to the cysteine-rich domains (CRDs) of the TNF receptors (TNFRs), and variations of these CRDs lead to heterogeneity of the TNFRs [103]. TNFRs are either constitutively expressed (TNFR1, p55-R) or inducible (TNFR2, p75-R) [104]. The inducible TNFR2 forms the basic architecture of etanercept, an FDA approved drug for treating severe rheumatoid arthritis and plaque psoriasis. In the context of neuropathic pain, using the CCI model in rats, TNF- $\alpha$ is detectable at the injury site in a temporal up-regulation [105-107], located mainly in both the macrophages [108] and the Schwann cells $[109,110]$. Similarly, there is local up-regulation of both TNFR1 and TNFR2 as the injured neurons undergo Wallerian degeneration, albeit at a differential rate [111]. Further upstream, there is enhanced TNF immunoreactivity in the dorsal root ganglion (DRG) of both the injured and spared ipsilateral adjacent afferents [112], plus the contralateral uninjured counterparts [113], which can only be partly explained by retrograde axonal transport [114]. There is also a corresponding up-regulation of TNFR1 and TNFR2 in both the nerve and the DRG [115], with a temporal pattern of an increase of TNF mRNA expression, first in the sciatic nerve, and then in the DRG [116]. Finally, glial TNF- $\alpha$ is thought to play a role in mediating the central mechanisms of neuropathic pain. Using classic CCI models in rats, increased levels of TNF- $\alpha$ are found in the hippocampus $[117,118]$, locus coeruleus $[118,119]$ and the red nucleus [120] of the brain. Albeit the ubiquity of TNF- $\alpha$ following experimental models of spinal cord injury, randomised controlled clinical trials of infliximab (antibody to TNF- $\alpha$ ) and etanercept (recombinant TNFR2) have not demonstrated benefits for patients with discogenic sciatica [121-124], which thwarted further research of anti-TNF- $\alpha$ treatment for other types of neuropathic pain. In comparison, clinical trial regarding the use of anti-TNF- $\alpha$ for spinal cord injury or related neuropathic pain is lacking, with only one case study reporting significant motor improvement and reduction of inflammation at the injured cord area of a patient who 
incidentally received etanercept treatment for ankylosing spondylitis shortly before a T7-cord transection accident [60](Table 1).

\section{Disinhibiting axonal regrowth: no go to nogo}

The spinal cord attempts to self-repair after any injury, which often ends in failure due to a combination of glial scar and growth inhibitors associated with myelin. Glial scar is formed by a congregation of meningeal fibroblasts, activated astrocytes, microglia and oligodendrocytes which on one hand, physically barricade the regenerating axons and on the other hand, secret an array of chondroitin sulphate proteoglycans (CSPGs) which chemically deter neurite outgrowths [125]. Presumably from the initial surge of Schwann cell activity to repair and myelinate the damaged axons [126], myelin-associated growth inhibitors like Nogo-A, myelinassociated glycoprotein (MAG) and oligodendrocytemyelin glycoprotein (OMG)[127] rapidly dominate the area and prevents further axonal growth and regeneration. Experiments with animal transgenic mutants deficient in these myelin-associated inhibitors have demonstrated better axonal growth and locomotory functions after spinal cord injury [128,129], which fosters the idea of antagonising these myelin-associated inhibitors to enable axonal re-growth and hence spinal cord regeneration. In 2010, a Phase I clinical trial of anti-Nogo-A in patients with acute spinal cord injury has been embarked by Zorner et al. [61](Table 1).

\section{Against cell cycle activation}

From animal experiments, there is evidence that cell cycling is activated during SCI which leads to neuronal cell death $[130,131]$, oligodendrocytes loss [131], inflammation [132,133], tissue scaring [134] and astrogliosis [132]. Increased cell cycling is seen by enhanced production of cycle proteins like cyclins [135], cyclin-activated kinases [136,137] and inhibitors of cyclindependent kinases [138]. It has been shown that cell cycle inhibitors are capable of reducing axonal damage and lead to functional recovery $[131,132,134]$ in animal models of spinal cord injury. Other inhibitory molecules that affect axonal regeneration in spinal cord injury include the Wnts molecules [139], semophorin 3 (SEMA3)[139] and the RhoA signalling pathway [140]. Despite the state of accumulated knowledge, no clinical trials have been approved or in progress to test the efficacy of these cell cycle inhibitors on patients with SCI.

\section{Neurotrophins: a friend or foe for spinal cord injury?}

Neurotrophins refer to the class of growth factors in the CNS that promote growth, maintenance and survival of neurons and synapses. They comprise of NGF, BDNF, NT-3 and NT-4/5 [40]. In rats and primates, the levels of neurotrophins peak initially in the embryonic stage where neurons and synapses are produced in abundance for matching and paring, after which the levels generally decline when inappropriate neurons and synapses are eliminated towards the adult neuronal profile [141,142]. Following acute hemisection of the spinal cord in Rhesus monkeys, the levels of NGF, BDNF and NT-3 decreased sharply from day 3 to Day 7 and increased persistently up to Day 30 [143], consistent with the attempt of intrinsic neuronal repair. Coupled with other experimental data showing that exogenously applied neurotrophins promote regeneration of various neuronal populations after various periods of spinal cord injury [144-146] even up to a period of 15 months [147], neurotrophins would be a promising therapy for spinal cord repair in humans. However, caution is needed in several areas when translating the positive findings from preclinical studies in rodents to clinical consideration: (i) there are species-specific differences in neuro-plasticity which necessitate regeneration of the corticospinal tracts in primates when restoring sensori-motor activities during spinal cord injury, but such pre-requisite is not shared by rodents [148]; (ii) the role and specificity of neurotrophins involved in promoting axonal regeneration and preventing corticospinal neuronal atrophy in spinal cord repair maybe different [149]; (iii) neurotrophins as therapy for CNS regeneration can lead to undesirable effects, e.g., exogenous administration of BDNF in experimental models can contribute to spinal nerve injury-induced neuropathic pain by activation of microglia [150] and astrocytes [151], whilst intra-cerebroventricular infusion of NGF leads to weight loss and neuropathic pain in one clinical pilot [152].

\section{Hurdles of cellular therapies in human}

Despite the promising prospect from various modalities as described above, there are a few hurdles to be surmounted before cellular therapies can be channelled towards large-scale clinical trials and eventual bedside use. For convenience of discussion, we shall choose stem cell therapy to illustrate such challenges.

\section{Cells generation and homogeneity}

There is as yet a standardised and efficient protocol to produce a specific type of stem cells in quantities large enough for clinical therapy. The combined protocol of feeder cells, growth factors and genetic modulation has been the traditional method for expanding the colonies of hESC [153] with average yield of $<20 \%$ [140], which in defined conditions can be enhanced to $95 \%$ with small molecule induction using retinoic acid [154]. In reality, it remains a technical challenge to conform stem cell differentiation to a particular phenotype, although a novel approach with nanofiber-scaffold drug release 
technology has recently been reported to be successful in committing MSC towards a neural differentiation [155]. Genome wide analysis has been used to monitor the quality and differentiation of $\mathrm{hESC}$ lines regarding the dynamics of "stemness genes"[156] and possible feeder contaminations [157]. It would be beneficial if transcriptomic and proteomic datasets are readily available for neuroscientists studying hECS to a degree as for studying OEC [158] and MSC [159].

\section{Cell dosing and delivery}

Dosing of stem cells in terms of upper limit and frequency of administration remains controversial. Intuitively one would expect an incremental response with dose escalations but available data is limited. Recent study by Usvald et al. [160] demonstrated an optimum dosing regimen for intra-parenchymal injection of human spinal stem cells into minipigs spinal cord for the best neuronal repopulation. Other studies have suggested that intra-thecal and intra-venous delivery of stem cells were less efficacious than direct injection into the spinal cord tissue, albeit the danger of further damage to the lesion [161,162]. Vaquero et al. [163] also showed that intra-lesional injection of stem cells in rats with SCI produced better outcome than intravenous administration. Thus said, it is still a challenge to target the stem cells within cellular precision. Recent study by $\mathrm{Wu}$ et al. [164] proposed the use of fibrin glue as a vehicle for delivering MSC to injured neural tissues.

\section{Cell tracking and outcome measure}

It would be ideal to track the stem cells after being administered to determine their distribution, location, quantity, viability and final differentiation for both research and clinical purposes. Non-invasive strategies include (i) direct labelling of target cells with paramagnetic contrast agents and tracking them with functional MRI, either using gadolinium $[165,166]$, supermagnetic iron oxide particles $[167,168]$, or ${ }^{19} \mathrm{~F}$ isotope [169]; (ii) direct labelling with traditional fluorochromes like PKH26 [170] or quantum dots using cadmium nanocrystals [171,172]; (iii) internal labelling using transfected enhanced green fluorescence protein (eGFP) and firefly luciferase (fLuc) reporter genes either via the bioluminescence mechanism $[173,174]$. Each of these cell tracking methods suffer from drawbacks: paramagnetic contrast uptake can be limited and MRI signals maybe weak (except using the supermagnetic iron oxide particles); traditional fluorochromes are prone to bleaching whilst cadmium in quantum dots crystals are toxic to cells; finally, bioluminescence imaging maybe be limited by the low tissue penetrance [175].

\section{Conclusions and future directions}

Spinal cord injury is a devastating condition in humans leading to significant disability with immense loss of quality of life and economic output. At time of writing, there is no satisfactory clinical cure and overall prognosis is poor. In the last two decades, experimental data using cellular or cell-related therapies have opened up exciting therapeutic possibilities. Various clinical studies using cellular therapies for spinal cord injury have been discussed above and are summarised in Table 1 for ease of reference. For spinal cord regeneration, stem cell transplantation still holds the best future and amongst them, hESC [176] and OEC [177] are currently the prime candidates. However, with the abrupt withdrawal of Geron from the GRNOPC1 Phase I clinical trial, the actual immaturity of hESC research in spinal cord injuries and its vulnerability to financial considerations is well illustrated [178]. As regards to combating neuropathic pain related to spinal cord injury, cellular or cellrelated therapies are rapidly gathering momentum which aim to achieve analgesia from different perspectives: preventing neuronal damage due to inflammation, cell cycling or dysfunctional regeneration; installing biological mini-pumps using adrenal medullary chromaffin tissues, engineered cell lines or astrocytes and finally, regulating the internal milieu using transplant of bone marrow of bone marrow mesenchymal stem cells.

\section{Abbreviations \\ 5-HT: 5-hydroxytrytamine; AMPA: a-amino-3-hydroxy-5-methyl-4- isoxazolepropionic acid; ASIA: American Spinal Injury Association; BDNF: Brian derived neurotrophic factor; CCl: Chronic constricting injury; CCL2: \\ Chemokine (C-C motif) ligand 2; CSF: Cerebrospinal fluid; CSPG: Chondroitin sulphate proteoglycans; CX3CL1: Chemokine (C-X3-C motif) ligand 1; DRG: Dorsal root ganglion; GABA: $\gamma$-aminobutyric acid; GAD: Glutamic acid decarboxylase; GDNF: Glial derived growth factor; GM-CSF: Granulocyte macrophage-colony stimulating factor; HB-GAM: Heparin-binding growth- associated molecule; HSV: Herpes simplex virus; IL-1 $\beta$ : Interleukin-1 beta; IL-6: Interleukin-6; MAG: Myelin-associated glycoprotein; MRI: Magnetic resonance imaging; MSC: Mesenchymal stem cells; NGF: Nerve growth factor; NMDA: N- Methyl-D-aspartic acid; NT-3: Neurotrophin-3; NT-4/5: Neurotrophin-4/5; OEC: Olfactory ensheathing cells; OMA: Olfactory mucosal autografts; OMG: Oligodendrocyte-myelin glycoprotein; PAG: Periaqueductal gray; PTN: Pleiotrophin; SCl: Spinal cord injury; SNI: Spinal nerve injury; THD: Tumor necrosis factor homology domain; TNF-a: Tumor necrosis factor alpha; TNFR: Tumor necrosis factor receptor; VAS: Visual analogue scale.}

\section{Author details}

${ }^{1}$ Centre of Neurosciences Study, Queen's University, 18 Stuart Street, Kingston, ON K7L 3N6, Canada. ${ }^{2}$ Centre of Studies in Primary Care, Queen's University, 220 Bagot Street, Kingston, ON K7L 5E9, Canada. ${ }^{3}$ Department of Family Medicine, Queen's University, 220 Bagot Street, Kingston, ON K7L 5E9, Canada.

Authors' contributions

$\mathrm{LL}$ performed the review and wrote the manuscript.

Competing interests

The author declares that they have no competing interests. 
Received: 8 October 2011 Accepted: 6 March 2012

Published: 6 March 2012

\section{References}

1. Sekhon LH, Fehlings MG: Epidemiology, demographics, and pathophysiology of acute spinal cord injury. Spine 2001, 26:S2-S12

2. Ning GZ, Yu TQ, Feng SQ, Zhou XH, Ban DX, Liu Y, Jiao XX: Epidemiology of traumatic spinal cord injury in Tianjin, China. Spinal Cord 2011, 49:386-390.

3. Hagen EM, Eide GE, Rekand T, Gilhus NE, Gronning M: A 50-year follow-up of the incidence of traumatic spinal cord injuries in Western Norway. Spinal Cord 2010, 48:313-318.

4. Yousefzadeh Chabok S, Safaee M, Alizadeh A, Ahmadi Dafchahi M, Taghinnejadi O, Koochakinejad L, Yousefzadeh Chabok S, Safaee M, Alizadeh A, Ahmadi Dafchahi M, Taghinnejadi O, Koochakinejad L: Epidemiology of traumatic spinal injury: a descriptive study. Acta medica Iranica 2010, 48:308-311.

5. Pickett GE, Campos-Benitez M, Keller JL, Duggal N: Epidemiology of traumatic spinal cord injury in Canada. Spine 2006, 31:799-805.

6. French DD, Campbell RR, Sabharwal S, Nelson AL, Palacios PA, GavinDreschnack D: Health care costs for patients with chronic spinal cord injury in the Veterans Health Administration. The journal of spinal cord medicine 2007, 30:477-481.

7. Price C, Makintubee S, Herndon W, Istre GR: Epidemiology of traumatic spinal cord injury and acute hospitalization and rehabilitation charges for spinal cord injuries in Oklahoma, 1988-1990. Am J Epidemiol 1994, 139:37-47

8. Siddall PJ: Management of neuropathic pain following spinal cord injury: now and in the future. Spinal cord: the official journal of the International Medical Society of Paraplegia 2009, 47:352-359.

9. Siddall PJ, McClelland JM, Rutkowski SB, Cousins MJ: A longitudinal study of the prevalence and characteristics of pain in the first 5 years following spinal cord injury. Pain 2003, 103:249-257.

10. Jensen MP, Kuehn CM, Amtmann D, Cardenas DD: Symptom burden in persons with spinal cord injury. Archives of physical medicine and rehabilitation 2007, 88:638-645.

11. Siddall PJ, Taylor DA, Cousins MJ: Classification of pain following spinal cord injury. Spinal cord: the official journal of the International Medical Society of Paraplegia 1997, 35:69-75.

12. Siddall PJ, Taylor DA, McClelland JM, Rutkowski SB, Cousins MJ: Pain report and the relationship of pain to physical factors in the first 6 months following spinal cord injury. Pain 1999, 81:187-197.

13. Turk D, Okifuji A: Treatment of chronic pain patients: clinical outcomes, cost-effectiveness, and cost-benefits of Multidisciplinary Pain Centers. Critical Reviews in Physical and Rehabilitation Medicine 1998, 10:181-208.

14. Mody I, MacDonald JF: NMDA receptor-dependent excitotoxicity: the role of intracellular Ca2+ release. Trends Pharmacol Sci 1995, 16:356-359.

15. Esposito E, Cuzzocrea S: Anti-TNF therapy in the injured spinal cord. Trends Pharmacol Sci 2011, 32:107-115.

16. Shu $X Q$, Llinas $A$, Mendell $L M$ : Effects of trkB and trkC neurotrophin receptor agonists on thermal nociception: a behavioral and electrophysiological study. Pain 1999, 80:463-470.

17. Zhou XF, Deng YS, Xian CJ, Zhong JH: Neurotrophins from dorsal root ganglia trigger allodynia after spinal nerve injury in rats. Eur J Neurosci 2000, 12:100-105.

18. Gao YJ, Ji RR: Chemokines, neuronal-glial interactions, and central processing of neuropathic pain. Pharmacol Ther 2010, 126:56-58

19. Scholz J, Woolf CJ: The neuropathic pain triad: neurons, immune cells and glia. Nat Neurosci 2007, 10:1361-1368.

20. Vallejo R, Tilley DM, Vogel L, Benyamin R: The role of glia and the immune system in the development and maintenance of neuropathic pain. Pain practice: the official journal of World Institute of Pain 2010, 10:167-184.

21. Moalem G, Tracey DJ: Immune and inflammatory mechanisms in neuropathic pain. Brain Res Rev 2006, 51:240-264.

22. Ichim TE, Riordan NH, Stroncek DF: The King is Dead. Long Live the King: Entering A New Era of Stem Cell Research and Clinical Development. Journal of translational medicine 2011, 9:218

23. Winn SR, Emerich DF: Managing chronic pain with encapsulated cell implants releasing catecholamines and endogenous opiods. Frontiers in bioscience: a journal and virtual library 2005, 10:367-378.
24. Henle J: Ueber das Gewebe der Nebermiere und der Hypophyse. $J$ Rationelle Med 1865, 24:143-152.

25. Hillarp NA, Lagerstedt $\mathrm{S}$, Nilson $\mathrm{B}$ : The isolation of a granular fraction from the suprarenal medulla, containing the sympathomimetic catechol amines. Acta physiologica Scandinavica 1953, 29:251-263.

26. Blaschko H, Welch AD: Localization of adrenaline in cytoplasmic particles of the bovine adrenal medulla. Naunyn-Schmiedebergs Archiv fur experimentelle Pathologie und Pharmakologie 1953, 219:17-22.

27. Bommer M, Herz A: Neuropeptides and other secretagogues in bovine chromaffin cells: their effect on opioid peptide metabolism. Neuropeptides 1989, 13:243-251.

28. Kondo H: Immunohistochemical analysis of the localization of neuropeptides in the adrenal gland. Archivum histologicum Japonicum Nippon soshikigaku kiroku 1985, 48:453-481.

29. Yang HY, Hexum T, Costa E: Opioid peptides in adrenal gland. Life Sci 1980, 27:1119-1125.

30. Livett BG, Dean DM, Whelan LG, Udenfriend S, Rossier J: Co-release of enkephalin and catecholamines from cultured adrenal chromaffin cells. Nature 1981, 289:317-319.

31. Wilson SP, Chang KJ, Viveros OH: Proportional secretion of opioid peptides and catecholamines from adrenal chromaffin cells in culture. The Journal of neuroscience: the official journal of the Society for Neuroscience 1982, 2:1150-1156.

32. Sagen J, Pappas GD, Pollard HB: Analgesia induced by isolated bovine chromaffin cells implanted in rat spinal cord. Proc Natl Acad Sci USA 1986, 83:7522-7526.

33. Sagen J, Pappas GD, Perlow MJ: Adrenal medullary tissue transplants in the rat spinal cord reduce pain sensitivity. Brain research 1986, 384:189-194.

34. Sagen J, Kemmler JE: Increased levels of Met-enkephalin-like immunoreactivity in the spinal cord CSF of rats with adrenal medullary transplants. Brain research 1989, 502:1-10.

35. Sagen J, Wang H: Prolonged analgesia by enkephalinase inhibition in rats with spinal cord adrenal medullary transplants. Eur J Pharmacol 1990, 179:427-433.

36. Sagen J, Wang H, Pappas GD: Adrenal medullary implants in the rat spinal cord reduce nociception in a chronic pain model. Pain 1990, 42:69-79.

37. Hama AT, Sagen J: Reduced pain-related behavior by adrenal medullary transplants in rats with experimental painful peripheral neuropathy. Pain 1993, 52:223-231.

38. Winnie AP, Pappas GD, Das Gupta TK, Wang H, Ortega JD, Sagen J: Subarachnoid adrenal medullary transplants for terminal cancer pain. $A$ report of preliminary studies. Anesthesiology 1993, 79:644-653.

39. Bes JC, Tkaczuk J, Czech KA, Tafani M, Bastide R, Caratero C, Pappas GD, Lazorthes $Y$ : One-year chromaffin cell allograft survival in cancer patients with chronic pain: morphological and functional evidence. Cell transplantation 1998, 7:227-238.

40. Lazorthes Y, Sagen J, Sallerin B, Tkaczuk J, Duplan H, Sol JC, Tafani M, Bes JC: Human chromaffin cell graft into the CSF for cancer pain management: a prospective phase II clinical study. Pain 2000, 87:19-32.

41. Wang H, Sagen J: Optimization of adrenal medullary allograft conditions for pain alleviation. Journal of neural transplantation \& plasticity 1994, 5:49-64.

42. Sagen J, Wang H, Tresco PA, Aebischer P: Transplants of immunologically isolated xenogeneic chromaffin cells provide a long-term source of pain-reducing neuroactive substances. The Journal of neuroscience: the official journal of the Society for Neuroscience 1993, 13:2415-2423.

43. Buchser E, Goddard M, Heyd B, Joseph JM, Favre J, de Tribolet N Lysaght M, Aebischer P: Immunoisolated xenogenic chromaffin cell therapy for chronic pain. Initial clinical experience. Anesthesiology 1996, 85:1005-1012, doi:discussion 1029A-1030A.

44. Miki K, Fukuoka T, Tokunaga A, Kondo E, Dai Y, Noguchi K: Differential effect of brain-derived neurotrophic factor on high-threshold mechanosensitivity in a rat neuropathic pain model. Neurosci Lett 2000, 278:85-88.

45. Moviglia GA, Fernandez Vina R, Brizuela JA, Saslavsky J, Vrsalovic F, Varela G, Bastos F, Farina P, Etchegaray G, Barbieri M, et al: Combined protocol of cell therapy for chronic spinal cord injury. Report on the electrical and functional recovery of two patients. Cytotherapy 2006, 8:202-209. 
46. Kishk NA, Gabr H, Hamdy S, Afifi L, Abokresha N, Mahmoud H, Wafaie A Bilal D: Case control series of intrathecal autologous bone marrow mesenchymal stem cell therapy for chronic spinal cord injury. Neurorehabilitation and neural repair 2010, 24:702-708.

47. Ichim TE, Solano F, Lara F, Paris E, Ugalde F, Rodriguez JP, Minev B, Bogin V, Ramos F, Woods EJ, et al: Feasibility of combination allogeneic stem cell therapy for spinal cord injury: a case report. International archives of medicine 2010, 3:30.

48. Sykova E, Homola A, Mazanec R, Lachmann H, Konradova SL, Kobylka P, Padr R, Neuwirth J, Komrska V, Vavra V, et al: Autologous bone marrow transplantation in patients with subacute and chronic spinal cord injury. Cell transplantation 2006, 15:675-687.

49. Yoon SH, Shim YS, Park YH, Chung JK, Nam JH, Kim MO, Park HC, Park SR, $\mathrm{Min} \mathrm{BH}$, Kim EY, et al: Complete spinal cord injury treatment using autologous bone marrow cell transplantation and bone marrow stimulation with granulocyte macrophage-colony stimulating factor: Phase I/II clinical trial. Stem cells 2007, 25:2066-2073.

50. Geffner LF, Santacruz P, Izurieta M, Flor L, Maldonado B, Auad AH, Montenegro X, Gonzalez R, Silva F: Administration of autologous bone marrow stem cells into spinal cord injury patients via multiple routes is safe and improves their quality of life: comprehensive case studies. Cell transplantation 2008, 17:1277-1293.

51. Kumar AA, Kumar SR, Narayanan R, Arul K, Baskaran M: Autologous bone marrow derived mononuclear cell therapy for spinal cord injury: $A$ phase I/II clinical safety and primary efficacy data. Experimental and clinical transplantation: official journal of the Middle East Society for Organ Transplantation 2009, 7:241-248.

52. Pal R, Venkataramana NK, Bansal A, Balaraju S, Jan M, Chandra R, Dixit A, Rauthan A, Murgod U, Totey S: Ex vivo-expanded autologous bone marrow-derived mesenchymal stromal cells in human spinal cord injury/ paraplegia: a pilot clinical study. Cytotherapy 2009, 11:897-911.

53. Feron F, Perry C, Cochrane J, Licina P, Nowitzke A, Urquhart S, Geraghty T, Mackay-Sim A: Autologous olfactory ensheathing cell transplantation in human spinal cord injury. Brain 2005, 128:2951-2960.

54. Mackay-Sim A, Feron F, Cochrane J, Bassingthwaighte L, Bayliss C, Davies W, Fronek P, Gray C, Kerr G, Licina P, et al: Autologous olfactory ensheathing cell transplantation in human paraplegia: a 3-year clinical trial. Brain 2008, 131:2376-2386.

55. Huang H, Chen L, Wang H, Xi H, Gou C, Zhang J, Zhang F, Liu Y: Safety of fetal olfactory ensheathing cell transplantation in patients with chronic spinal cord injury. A 38-month follow-up with MRI. Zhongguo Xiu Fu Chong Jian Wai Ke Za Zhi 2006, 20:439-443.

56. Lima C, Pratas-Vital J, Escada P, Hasse-Ferreira A, Capucho C, Peduzzi JD: Olfactory mucosa autografts in human spinal cord injury: a pilot clinical study. J Spinal Cord Med 2006, 29:191-203, discussion 204-196.

57. Lima C, Escada P, Pratas-Vital J, Branco C, Arcangeli CA, Lazzeri G, Maia CA, Capucho C, Hasse-Ferreira A, Peduzzi JD: Olfactory mucosal autografts and rehabilitation for chronic traumatic spinal cord injury. Neurorehabil Neural Repair 2010, 24:10-22.

58. Chhabra HS, Lima C, Sachdeva S, Mittal A, Nigam V, Chaturvedi D, Arora M, Aggarwal A, Kapur R, Khan TA: Autologous olfactory [corrected] mucosal transplant in chronic spinal cord injury: an Indian Pilot Study. Spinal Cord 2009, 47:887-895.

59. Saberi H, Moshayedi P, Aghayan HR, Arjmand B, Hosseini SK, EmamiRazavi SH, Rahimi-Movaghar V, Raza M, Firouzi M: Treatment of chronic thoracic spinal cord injury patients with autologous Schwann cell transplantation: an interim report on safety considerations and possible outcomes. Neurosci Lett 2008, 443:46-50.

60. Dinomais M, Stana L, Egon G, Richard I, Menei P: Significant recovery of motor function in a patient with complete T7 paraplegia receiving etanercept. J Rehabil Med 2009, 41:286-288.

61. Zorner B, Schwab ME: Anti-Nogo on the go: from animal models to a clinical trial. Ann N Y Acad Sci 2010, 1198(Suppl 1):E22-E34

62. Eaton MJ, Plunkett JA, Martinez MA, Lopez T, Karmally S, Cejas P, Whittemore SR: Transplants of neuronal cells bioengineered to synthesize GABA alleviate chronic neuropathic pain. Cell transplantation 1999, 8:87-101.

63. Eaton MJ, Martinez M, Karmally S, Lopez T, Sagen J: Initial characterization of the transplant of immortalized chromaffin cells for the attenuation of chronic neuropathic pain. Cell transplantation 2000, 9:637-656.
64. Eaton MJ, Karmally S, Martinez MA, Plunkett JA, Lopez T, Cejas PJ: Lumbar transplant of neurons genetically modified to secrete galanin reverse pain-like behaviors after partial sciatic nerve injury. Journal of the peripheral nervous system: JPNS 1999, 4:245-257.

65. Cejas PJ, Martinez M, Karmally S, McKillop M, McKillop J, Plunkett JA, Oudega M, Eaton MJ: Lumbar transplant of neurons genetically modified to secrete brain-derived neurotrophic factor attenuates allodynia and hyperalgesia after sciatic nerve constriction. Pain 2000, 86:195-210.

66. $\mathrm{Xu} \mathrm{Y,} \mathrm{Tian} \mathrm{XB}, \mathrm{An} \mathrm{K}$, Yang $\mathrm{H}$, Tian YK: Lumbar transplantation of immortalized enkephalin-expressing astrocytes attenuates chronic neuropathic pain. European journal of pain 2008, 12:525-533.

67. An K, Xu Y, Yang H, Shu HH, Xiang HB, Tian YK: Subarachnoid transplantation of immortalized galanin-overexpressing astrocytes attenuates chronic neuropathic pain. European journal of pain 2010, 14:595-601.

68. Liu J, Wolfe D, Hao S, Huang S, Glorioso JC, Mata M, Fink DJ: Peripherally delivered glutamic acid decarboxylase gene therapy for spinal cord injury pain. Molecular therapy: the journal of the American Society of Gene Therapy 2004, 10:57-66

69. Lee JY, Fink DJ, Mata M: Vector-mediated gene transfer to express inhibitory neurotransmitters in dorsal root ganglion reduces pain in a rodent model of lumbar radiculopathy. Spine 2006, 31:1555-1558.

70. Miyazato M, Sugaya K, Goins WF, Wolfe D, Goss JR, Chancellor MB, de Groat WC, Glorioso JC, Yoshimura N: Herpes simplex virus vectormediated gene delivery of glutamic acid decarboxylase reduces detrusor overactivity in spinal cord-injured rats. Gene therapy 2009, 16:660-668.

71. Wolfe D, Mata M, Fink DJ: A human trial of HSV-mediated gene transfer for the treatment of chronic pain. Gene therapy 2009, 16:455-460.

72. Beyer Nardi N, da Silva Meirelles L: Mesenchymal stem cells: isolation, in vitro expansion and characterization. Handbook of experimental pharmacology 2006, 249-282.

73. Le Blanc K, Pittenger M: Mesenchymal stem cells: progress toward promise. Cytotherapy 2005, 7:36-45.

74. Scuteri A, Miloso M, Foudah D, Orciani M, Cavaletti G, Tredici G: Mesenchymal Stem Cells Neuronal Differentiation Ability: A Real Perspective for Nervous System Repair? Current stem cell research \& therapy 2010.

75. Bae JS, Han HS, Youn DH, Carter JE, Modo M, Schuchman EH, Jin HK: Bone marrow-derived mesenchymal stem cells promote neuronal networks with functional synaptic transmission after transplantation into mice with neurodegeneration. Stem cells 2007, 25:1307-1316.

76. Siniscalco D, Giordano C, Galderisi U, Luongo L, Alessio N, Di Bernardo G, de Novellis $V$, Rossi F, Maione S: Intra-brain microinjection of human mesenchymal stem cells decreases allodynia in neuropathic mice. Cellular and molecular life sciences: CMLS 2010, 67:655-669.

77. Moviglia GA, Varela G, Gaeta CA, Brizuela JA, Bastos F, Saslavsky J: Autoreactive $T$ cells induce in vitro BM mesenchymal stem cell transdifferentiation to neural stem cells. Cytotherapy 2006, 8:196-201.

78. Fawcett JW, Curt A, Steeves JD, Coleman WP, Tuszynski MH, Lammertse D, Bartlett PF, Blight AR, Dietz V, Ditunno J, et al: Guidelines for the conduct of clinical trials for spinal cord injury as developed by the ICCP panel: spontaneous recovery after spinal cord injury and statistical power needed for therapeutic clinical trials. Spinal Cord 2007, 45:190-205.

79. Huard JM, Youngentob SL, Goldstein BJ, Luskin MB, Schwob JE: Adult olfactory epithelium contains multipotent progenitors that give rise to neurons and non-neural cells. J Comp Neurol 1998, 400:469-486.

80. Franklin RJ: Remyelination by transplanted olfactory ensheathing cells. Anat Rec B New Anat 2003, 271:71-76.

81. Boyd JG, Skihar V, Kawaja M, Doucette R: Olfactory ensheathing cells: historical perspective and therapeutic potential. Anat Rec B New Anat 2003, 271:49-60

82. Boyd JG, Doucette R, Kawaja MD: Defining the role of olfactory ensheathing cells in facilitating axon remyelination following damage to the spinal cord. FASEB J 2005, 19:694-703.

83. Keyvan-Fouladi N, Li Y, Raisman G: How do transplanted olfactory ensheathing cells restore function? Brain Res Brain Res Rev 2002, 40:325-327.

84. Gomez VM, Averill S, King V, Yang Q, Doncel Perez E, Chacon SC, Ward R, Nieto-Sampedro M, Priestley J, Taylor J: Transplantation of olfactory 
ensheathing cells fails to promote significant axonal regeneration from dorsal roots into the rat cervical cord. J Neurocytol 2003, 32:53-70.

85. Riddell JS, Enriquez-Denton M, Toft A, Fairless R, Barnett SC: Olfactory ensheathing cell grafts have minimal influence on regeneration at the dorsal root entry zone following rhizotomy. Glia 2004, 47:150-167.

86. Ramer LM, Richter MW, Roskams AJ, Tetzlaff W, Ramer MS: Peripherallyderived olfactory ensheathing cells do not promote primary afferent regeneration following dorsal root injury. Glia 2004, 47:189-206.

87. Boyd JG, Jahed A, McDonald TG, Krol KM, Van Eyk JE, Doucette R, Kawaja MD: Proteomic evaluation reveals that olfactory ensheathing cells but not Schwann cells express calponin. Glia 2006, 53:434-440,

88. Rizek PN, Kawaja MD: Cultures of rat olfactory ensheathing cells are contaminated with Schwann cells. NeuroReport 2006, 17:459-462.

89. Kawaja MD, Boyd JG, Smithson L, Jahed A, Doucette R: Technical strategies to isolate olfactory ensheathing cells for intraspinal implantation. J Neurotrauma 2009, 26:155-177.

90. Buss A, Pech K, Kakulas BA, Martin D, Schoenen J, Noth J, Brook GA: Growth-modulating molecules are associated with invading Schwann cells and not astrocytes in human traumatic spinal cord injury. Brain: a journal of neurology 2007, 130:940-953.

91. Takami T, Oudega M, Bates ML, Wood PM, Kleitman N, Bunge MB Schwann cell but not olfactory ensheathing glia transplants improve hindlimb locomotor performance in the moderately contused adult rat thoracic spinal cord. The Journal of neuroscience: the official journal of the Society for Neuroscience 2002, 22:6670-6681.

92. Beattie MS, Bresnahan JC, Komon J, Tovar CA, Van Meter M, Anderson DK, Faden Al, Hsu CY, Noble L, Salzman S, Young W: Endogenous repair after spinal cord contusion injuries in the rat. Exp Neurol 1997, 148:453-463.

93. Blight AR, Young W: Central axons in injured cat spinal cord recover electrophysiological function following remyelination by Schwann cells. J Neurol Sci 1989, 91:15-34.

94. Brown A, Ricci MJ, Weaver LC: NGF message and protein distribution in the injured rat spinal cord. Exp Neurol 2004, 188:115-127.

95. Yamamoto M, Sobue G, Li M, Arakawa Y, Mitsuma T, Kimata K: Nerve growth factor (NGF), brain-derived neurotrophic factor (BDNF) and lowaffinity nerve growth factor receptor (LNGFR) mRNA levels in cultured rat Schwann cells; differential time- and dose-dependent regulation by cAMP. Neurosci Lett 1993, 152:37-40.

96. Lapointe NP, Ung RV, Guertin PA: Plasticity in sublesionally located neurons following spinal cord injury. J Neurophysiol 2007, 98:2497-2500.

97. Widenfalk J, Lundstromer K, Jubran M, Brene S, Olson L: Neurotrophic factors and receptors in the immature and adult spinal cord after mechanical injury or kainic acid. The Journal of neuroscience: the official journal of the Society for Neuroscience 2001, 21:3457-3475.

98. Wang YT, Han S, Zhang KH, Jin Y, Xu XM, Lu PH: Upregulation of heparinbinding growth-associated molecule after spinal cord injury in adult rats. Acta pharmacologica Sinica 2004, 25:611-616.

99. Hoke A, Redett R, Hameed H, Jari R, Zhou C, Li ZB, Griffin JW, Brushart TM: Schwann cells express motor and sensory phenotypes that regulate axon regeneration. The Journal of neuroscience: the official journal of the Society for Neuroscience 2006, 26:9646-9655.

100. Sahin B, Albayrak BS, Ismailoglu O, Gorgulu A: The effects of medroxy progesterone acetate on the pro-inflammatory cytokines, TNF-alpha and IL-1beta in the early phase of the spinal cord injury. Neurol Res 2011, 33:63-67.

101. Bickels J, Kollender Y, Merinsky O, Meller I: Coley's toxin: historical perspective. Isr Med Assoc J 2002, 4:471-472.

102. Carswell EA, Old LJ, Kassel RL, Green S, Fiore N, Williamson B: An endotoxin-induced serum factor that causes necrosis of tumors. Proc Natl Acad Sci USA 1975, 72:3666-3670

103. Bodmer JL, Schneider P, Tschopp J: The molecular architecture of the TNF superfamily. Trends Biochem Sci 2002, 27:19-26.

104. Locksley RM, Killeen N, Lenardo MJ: The TNF and TNF receptor superfamilies: integrating mammalian biology. Cell 2001, 104:487-501.

105. George A, Schmidt C, Weishaupt A, Toyka KV, Sommer C: Serial determination of tumor necrosis factor-alpha content in rat sciatic nerve after chronic constriction injury. Exp Neurol 1999, 160:124-132.

106. George A, Buehl A, Sommer C: Wallerian degeneration after crush injury of rat sciatic nerve increases endo- and epineurial tumor necrosis factoralpha protein. Neurosci Lett 2004, 372:215-219.
107. Shubayev VI, Myers RR: Upregulation and interaction of TNFalpha and gelatinases A and B in painful peripheral nerve injury. Brain Res 2000, 855:83-89

108. Sommer C, Schafers M: Painful mononeuropathy in C57BL/WId mice with delayed wallerian degeneration: differential effects of cytokine production and nerve regeneration on thermal and mechanical hypersensitivity. Brain Res 1998, 784:154-162.

109. Wagner R, Myers RR: Schwann cells produce tumor necrosis factor alpha: expression in injured and non-injured nerves. Neuroscience 1996, 73:625-629.

110. Shamash S, Reichert F, Rotshenker S: The cytokine network of Wallerian degeneration: tumor necrosis factor-alpha, interleukin-1alpha, and interleukin-1 beta. J Neurosci 2002, 22:3052-3060.

111. George A, Buehl A, Sommer C: Tumor necrosis factor receptor 1 and 2 proteins are differentially regulated during Wallerian degeneration of mouse sciatic nerve. Exp Neurol 2005, 192:163-166.

112. Schafers M, Geis C, Svensson Cl, Luo ZD, Sommer C: Selective increase of tumour necrosis factor-alpha in injured and spared myelinated primary afferents after chronic constrictive injury of rat sciatic nerve. Eur J Neurosci 2003, 17:791-804.

113. Jancalek R, Dubovy P, Svizenska I, Klusakova I: Bilateral changes of TNFalpha and IL-10 protein in the lumbar and cervical dorsal root ganglia following a unilateral chronic constriction injury of the sciatic nerve. $J$ Neuroinflammation 2010, 7:11.

114. Shubayev VI, Myers RR: Axonal transport of TNF-alpha in painful neuropathy: distribution of ligand tracer and TNF receptors. Neuroimmunol 2001, 114:48-56.

115. Schafers M, Sorkin LS, Geis C, Shubayev VI: Spinal nerve ligation induces transient upregulation of tumor necrosis factor receptors 1 and 2 in injured and adjacent uninjured dorsal root ganglia in the rat. Neurosci Lett 2003, 347:179-182.

116. Sacerdote P, Franchi S, Trovato AE, Valsecchi AE, Panerai AE, Colleoni M: Transient early expression of TNF-alpha in sciatic nerve and dorsal root ganglia in a mouse model of painful peripheral neuropathy. Neurosci Lett 2008, 436:210-213.

117. Ignatowski TA, Covey WC, Knight PR, Severin CM, Nickola TJ, Spengler RN: Brain-derived TNFalpha mediates neuropathic pain. Brain Res 1999, 841:70-77.

118. Covey WC, Ignatowski TA, Knight PR, Spengler RN: Brain-derived TNFalpha: involvement in neuroplastic changes implicated in the conscious perception of persistent pain. Brain Res 2000, 859:113-122.

119. Covey WC, Ignatowski TA, Renauld AE, Knight PR, Nader ND, Spengler RN: Expression of neuron-associated tumor necrosis factor alpha in the brain is increased during persistent pain. Reg Anesth Pain Med 2002, 27:357-366.

120. Li X, Wang J, Wang Z, Dong C, Dong X, Jing Y, Yuan Y, Fan G: Tumor necrosis factor-alpha of Red nucleus involved in the development of neuropathic allodynia. Brain Res Bull 2008.

121. Korhonen T, Karppinen J, Malmivaara A, Autio R, Niinimaki J, Paimela L, Kyllonen E, Lindgren KA, Tervonen O, Seitsalo S, Hurri H: Efficacy of infliximab for disc herniation-induced sciatica: one-year follow-up. Spine 2004, 29:2115-2119.

122. Korhonen T, Karppinen J, Paimela L, Malmivaara A, Lindgren KA, Jarvinen S, Niinimaki J, Veeger N, Seitsalo S, Hurri H: The treatment of disc herniationinduced sciatica with infliximab: results of a randomized, controlled, 3month follow-up study. Spine 2005, 30:2724-2728.

123. Korhonen T, Karppinen J, Paimela L, Malmivaara A, Lindgren KA, Bowman C, Hammond A, Kirkham B, Jarvinen S, Niinimaki J, et al: The treatment of disc-herniation-induced sciatica with infliximab: one-year follow-up results of FIRST II, a randomized controlled trial. Spine 2006, 31:2759-2766.

124. Cohen SP, Wenzell D, Hurley RW, Kurihara C, Buckenmaier CC, Griffith S, Larkin TM, Dahl E, Morlando BJ: A double-blind, placebo-controlled, doseresponse pilot study evaluating intradiscal etanercept in patients with chronic discogenic low back pain or lumbosacral radiculopathy. Anesthesiology 2007, 107:99-105.

125. Buss A, Brook GA, Kakulas B, Martin D, Franzen R, Schoenen J, Noth J, Schmitt AB: Gradual loss of myelin and formation of an astrocytic scar during Wallerian degeneration in the human spinal cord. Brain: a journal of neurology 2004, 127:34-44.

126. Franklin RJ, Blakemore WF: Requirements for Schwann cell migration within CNS environments: a viewpoint. Int J Dev Neurosci 1993, 11:641-649. 
127. David S, Lacroix S: Molecular approaches to spinal cord repair. Annu Rev Neurosci 2003, 26:411-440.

128. Cafferty WB, Duffy P, Huebner E, Strittmatter SM: MAG and OMgp synergize with Nogo-A to restrict axonal growth and neurological recovery after spinal cord trauma. The Journal of neuroscience: the official journal of the Society for Neuroscience 2010, 30:6825-6837.

129. Hu JG, Lu PH, Xu XM: Inhibitory proteins against axon regeneration in the central nervous system. Sheng li ke xue jin zhan [Progress in physiology] 2004, 35:311-314.

130. Di Giovanni S, Knoblach SM, Brandoli C, Aden SA, Hoffman EP, Faden Al: Gene profiling in spinal cord injury shows role of cell cycle in neuronal death. Ann Neurol 2003, 53:454-468.

131. Byrnes KR, Stoica BA, Fricke S, Di Giovanni S, Faden Al: Cell cycle activation contributes to post-mitotic cell death and secondary damage after spinal cord injury. Brain 2007, 130:2977-2992.

132. Tian DS, Xie MJ, Yu ZY, Zhang Q, Wang YH, Chen B, Chen C, Wang W: Cell cycle inhibition attenuates microglia induced inflammatory response and alleviates neuronal cell death after spinal cord injury in rats. Brain Res 2007, 1135:177-185.

133. Cernak I, Stoica B, Byrnes KR, Di Giovanni S, Faden Al: Role of the cell cycle in the pathobiology of central nervous system trauma. Cell Cycle 2005, 4:1286-1293.

134. Tian DS, Yu ZY, Xie MJ, Bu BT, Witte OW, Wang W: Suppression of astroglial scar formation and enhanced axonal regeneration associated with functional recovery in a spinal cord injury rat model by the cell cycle inhibitor olomoucine. J Neurosci Res 2006, 84:1053-1063.

135. Sherr CJ: Mammalian G1 cyclins. Cell 1993, 73:1059-1065.

136. Nishitani H, Lygerou Z: Control of DNA replication licensing in a cell cycle. Genes to cells: devoted to molecular \& cellular mechanisms 2002, 7:523-534

137. Obaya AJ, Sedivy JM: Regulation of cyclin-Cdk activity in mammalian cells. Cellular and molecular life sciences: CMLS 2002, 59:126-142.

138. Fischer PM, Endicott J, Meijer L: Cyclin-dependent kinase inhibitors. Prog Cell Cycle Res 2003, 5:235-248.

139. Liu Y, Wang X, Lu CC, Kerman R, Steward O, Xu XM, Zou Y: Repulsive Wnt signaling inhibits axon regeneration after CNS injury. J Neurosci 2008, 28:8376-8382

140. Yiu G, He Z: Glial inhibition of CNS axon regeneration. Nat Rev Neurosci 2006, 7:617-627.

141. Dehlin O, Rubin B, Rundgren A: Double-blind comparison of zopiclone and flunitrazepam in elderly insomniacs with special focus on residual effects. Curr Med Res Opin 1995, 13:317-324.

142. Klimm HD, Dreyfus JF, Delmotte M: Zopiclone versus nitrazepam: a double-blind comparative study of efficacy and tolerance in elderly patients with chronic insomnia. Sleep 1987, 10(Suppl 1):73-78.

143. Dehlin O, Bjornson G: Triazolam as a hypnotic for geriatric patients. A double-blind cross-over comparison of nitrazepam and triazolam regarding effects on sleep and psychomotor performance. Acta Psychiatr Scand 1983, 67:290-296.

144. Small GW, Bystritsky A: Double-blind, placebo-controlled trial of two doses of abecarnil for geriatric anxiety. J Clin Psychiatry 1997, 58(Suppl 11):24-29.

145. Lu P, Jones LL, Tuszynski MH: BDNF-expressing marrow stromal cells support extensive axonal growth at sites of spinal cord injury. Exp Neurol 2005, 191:344-360

146. Tuszynski MH, Grill R, Jones LL, Brant A, Blesch A, Low K, Lacroix S, Lu P: NT-3 gene delivery elicits growth of chronically injured corticospinal axons and modestly improves functional deficits after chronic scar resection. Exp Neurol 2003, 181:47-56.

147. Kadoya K, Tsukada S, Lu P, Coppola G, Geschwind D, Filbin MT, Blesch A, Tuszynski MH: Combined intrinsic and extrinsic neuronal mechanisms facilitate bridging axonal regeneration one year after spinal cord injury. Neuron 2009, 64:165-172.

148. Lemon RN, Griffiths J: Comparing the function of the corticospinal system in different species: organizational differences for motor specialization? Muscle Nerve 2005, 32:261-279.

149. Brock JH, Rosenzweig ES, Blesch A, Moseanko R, Havton LA, Edgerton VR, Tuszynski MH: Local and remote growth factor effects after primate spinal cord injury. The Journal of neuroscience: the official journal of the Society for Neuroscience 2010, 30:9728-9737.
150. Morin CM, Bastien CH, Brink D, Brown TR: Adverse effects of temazepam in older adults with chronic insomnia. Hum Psychopharmacol 2003, 18:75-82.

151. Bayer AJ, Pathy MS: Clinical and psychometric evaluation of two doses of loprazolam and placebo in geriatric patients. Curr Med Res Opin 1986, 10:17-24.

152. Eriksdotter Jonhagen M, Nordberg A, Amberla K, Backman L, Ebendal T, Meyerson B, Olson L, Shigeta M, Theodorsson E, et al: Intracerebroventricular infusion of nerve growth factor in three patients with Alzheimer's disease. Dementia and geriatric cognitive disorders 1998, 9:246-257.

153. Silver J, Miller JH: Regeneration beyond the glial scar. Nat Rev Neurosci 2004, 5:146-156.

154. Parsons XH, Teng YD, Parsons JF, Snyder EY, Smotrich DB, Moore DA: Efficient derivation of human neuronal progenitors and neurons from pluripotent human embryonic stem cells with small molecule induction. $J$ Vis Exp 2011, 56:e3273.

155. Jiang X, Cao HQ, Shi LY, Ng SY, Stanton LW, Chew SY: Nanofiber topography and sustained biochemical signaling enhance human mesenchymal stem cell neural commitment. Acta Biomater 2012, 8:1290-1302.

156. Bhattacharya B, Puri S, Puri RK: A review of gene expression profiling of human embryonic stem cell lines and their differentiated progeny. Current stem cell research \& therapy 2009, 4:98-106.

157. Liu Y, Shin S, Zeng X, Zhan M, Gonzalez R, Mueller FJ, Schwartz CM, Xue H, Li H, Baker SC, et al: Genome wide profiling of human embryonic stem cells (hESCs), their derivatives and embryonal carcinoma cells to develop base profiles of U.S. Federal government approved hESC lines. BMC developmental biology 2006, 6:20.

158. Roet KC, Bossers K, Franssen EH, Ruitenberg MJ, Verhaagen J: A metaanalysis of microarray-based gene expression studies of olfactory bulbderived olfactory ensheathing cells. Exp Neurol 2011, 229:10-45.

159. Menssen A, Haupl T, Sittinger M, Delorme B, Charbord P, Ringe J: Differential gene expression profiling of human bone marrow-derived mesenchymal stem cells during adipogenic development. BMC genomics 2011, 12:461.

160. Usvald D, Vodicka P, Hlucilova J, Prochazka R, Motlik J, Kuchorova K, Johe K, Marsala S, Scadeng M, Kakinohana O, et al: Analysis of dosing regimen and reproducibility of intraspinal grafting of human spinal stem cells in immunosuppressed minipigs. Cell Transplant 2010, 19:1103-1122.

161. Vaquero J, Zurita M, Oya S, Santos M: Cell therapy using bone marrow stromal cells in chronic paraplegic rats: systemic or local administration? Neurosci Lett 2006, 398:129-134.

162. Khalatbary AR, Tiraihi T: A comparative study of therapeutic benefits of intraspinal and intravenous bone marrow stromal cell administration to spinal cord injuries. Iran Biomed J 2009, 13:43-48.

163. Vaquero J, Zurita M: Bone marrow stromal cells for spinal cord repair: a challenge for contemporary neurobiology. Histol Histopathol 2009, 24:107-116.

164. Wu X, Ren J, Li J: Fibrin glue as the cell-delivery vehicle for mesenchymal stromal cells in regenerative medicine. Cytotherapy 2011.

165. Liu Y, He ZJ, Xu B, Wu QZ, Liu G, Zhu H, Zhong Q, Deng DY, Ai H, Yue Q et al: Evaluation of cell tracking effects for transplanted mesenchymal stem cells with jetPEl/Gd-DTPA complexes in animal models of hemorrhagic spinal cord injury. Brain Res 2011, 1391:24-35.

166. Rudelius M, Daldrup-Link HE, Heinzmann U, Piontek G, Settles M, Link TM, Schlegel J: Highly efficient paramagnetic labelling of embryonic and neuronal stem cells. Eur J Nucl Med Mol Imaging 2003, 30:1038-1044.

167. Sykova E, Jendelova P: In vivo tracking of stem cells in brain and spinal cord injury. Progress in brain research 2007, 161:367-383.

168. Kallur T, Farr TD, Bohm-Sturm P, Kokaia Z, Hoehn M: Spatio-temporal dynamics, differentiation and viability of human neural stem cells after implantation into neonatal rat brain. Eur I Neurosci 2011, 34:382-393.

169. Boehm-Sturm P, Mengler L, Wecker S, Hoehn M, Kallur T: In vivo tracking of human neural stem cells with $\mathrm{f}$ magnetic resonance imaging. PLoS One 2011, 6:e29040.

170. Seyed Jafari SS, Ali Aghaei A, Asadi-Shekaari M, Nematollahi-Mahani SN, Sheibani V: Investigating the effects of adult neural stem cell transplantation by lumbar puncture in transient cerebral ischemia. Neurosci Lett 2011, 495:1-5. 
171. Lu S, Xu X, Zhao W, Wu W, Yuan H, Shen H, Zhou C, Li LS, Ma L: Targeting of embryonic stem cells by peptide-conjugated quantum dots. PLoS One 2010, 5:e12075.

172. Shah BS, Mao JJ: Labeling of mesenchymal stem cells with bioconjugated quantum dots. Methods Mol Biol 2011, 680:61-75.

173. Daadi MM, Li Z, Arac A, Grueter BA, Sofilos M, Malenka RC, Wu JC, Steinberg GK: Molecular and magnetic resonance imaging of human embryonic stem cell-derived neural stem cell grafts in ischemic rat brain. Molecular therapy: the journal of the American Society of Gene Therapy 2009, 17:1282-1291.

174. Swijnenburg RJ, Schrepfer S, Cao F, Pearl Jl, Xie X, Connolly AJ, Robbins RC, Wu JC: In vivo imaging of embryonic stem cells reveals patterns of survival and immune rejection following transplantation. Stem Cells Dev 2008, 17:1023-1029.

175. de Almeida PE, van Rappard JR, Wu JC: In vivo bioluminescence for tracking cell fate and function. Am J Physiol Heart Circ Physiol 2011, 301: H663-H671.

176. Stenson K, Chen D, Tansey K, Kerkhoff TR, Butt L, Gallegos AJ, Kirschner KL: Informed consent and phase 1 research in spinal cord injury. $P M \& R$ : the journal of injury, function, and rehabilitation 2010, 2:664-670.

177. Sobani ZA, Quadri SA, Enam SA: Stem cells for spinal cord regeneration: Current status. Surgical neurology international 2010, 1:93.

178. Frantz S: Embryonic stem cell pioneer Geron exits field, cuts losses. Nat Biotechnol 2012, 30:12-13.

doi:10.1186/1479-5876-10-37

Cite this article as: Leung: Cellular therapies for treating pain associated with spinal cord injury. Journal of Translational Medicine 2012 10:37.

\section{Submit your next manuscript to BioMed Central and take full advantage of:}

- Convenient online submission

- Thorough peer review

- No space constraints or color figure charges

- Immediate publication on acceptance

- Inclusion in PubMed, CAS, Scopus and Google Scholar

- Research which is freely available for redistribution

Submit your manuscript at www.biomedcentral.com/submit 